\title{
Surface View of the Capillary of the Pecten Oculi in the Common Finch (Uroloncha Striata Domestica)
}

\author{
By \\ Arata SUGITA, Masahiro MURAKAMI and Yoshihisa INOUE \\ Department of Anatomy, Kurume University School \\ of Medicine, Kurume 830, Japan \\ -Received for Publication, August 21, 1981-
}

\begin{abstract}
Key words: Capillary, Endothelial cell, Pecten Oculi, Pericyte, Scanning electron microscopy

Summary : The basal and luminal surfaces of the capillary of the pecten oculi in the common finch (Uroloncha striata domestica) were investigated by scanning electron microscopy. A dense network of capillaries could be exposed by treatment with collagenase and $\mathrm{HCl}$. The pericytes on the stromal surface of the capillary wall were sparse in distribution and were in close contact with the endothelial cells of the capillary. The basal processes of the endothelial cells of the capillary were composed of microfolds which anastomosed with each other. On the fractured surface of the capillary, the luminal surface of the endothelial cells was occupied by microvilli and microfolds. The differentiation of the endothelial cell membrane into basal and luminal surfaces in the pectineal capillary may play the role of expansion of the receptive surface area to membrane-bound enzymes.
\end{abstract}

The pecten of the avian eye is a richly vascularized organ, projecting from the optic disc into the vitreous body. Since the avian retina is thick and lacks a vascular system, it seems reasonable to assume that the pecten oculi exerts metabolic and nutritive effects on the inner layers of the retina. Nevertheless, the functional significance of the pecten still remains obscure and in dispute.

Transmission electron microscope(TEM) examinations have shown that the endothelial cells of the capillary of the pecten oculi possess cytoplasmic processes at both margins (Tanaka, 1960 ; Semba, 1962: Seaman and Storm, 1963; Fischlschweiger and O'Rahilly, 1966; Raviola and Raviola, 1967; Welsch, 1972; Jasinski, 1973; Die- terich et al., 1973; Dieterich and Dieterich, 1974; Amemiya, 1980). Discrepancies, however, exist in the literature concerning the precise morphology of these cytoplasmic processes of the endothelial cells of the capillary.

The main purpose of the present study was to clarify the basal and luminal specializations of the endothelial surface of the pectineal capillary three-dimensionally under the scanning electron microscope (SEM). The collagenase- $\mathrm{HCl}$ method was also employed to expose the basal surface of the capillary.

\section{Materials and Methods}

Adult common finches (Uroloncha stri- 
ata domestica) were used. Under ether anesthesia, the eye was enucleated and hemidissected along its meridian plane with a razor blade. The pecten oculi was quickly dissected and placed in collagenase solution for $2-4$ hours at $37^{\circ} \mathrm{C}$. The concentration of collagenase (Sigma, type II) was $10 \mathrm{mg}$ in $10 \mathrm{cc}$ of $0.1 \mathrm{M}$ phosphate buffer ( $\mathrm{pH}$ 6.8). After collagenase digestion, the tissue was fixed with $2.5 \%$ glutaraldehyde and $2 \%$ paraformaldehyde in $0.1 \mathrm{M}$ cacodylate buffer ( $\mathrm{pH}$ 7.4) for more than 3 hours. It was rinsed several times in $0.1 \mathrm{M}$ phosphate buffer and then placed in $8 \mathrm{~N} \mathrm{HCl}$ for $15-30$ minutes at $60^{\circ} \mathrm{C}$.

Compared to the original HCl-collagenase method of Evan et al. (1976), a modification was employed in this study. This was characterized by shorter periods of $\mathrm{HCl}$ treatment for better preservation of the structural integrity of the cell surface without pitting of the cell surface.

The material was further postfixed in cacodylate buffered osmium tetroxide ( $\mathrm{pH}$ 7.4) for 2 hours, dehydrated in an acetone series and dried by the critical point method using liquid $\mathrm{CO}_{2}$. After sputtercoating with gold, the sample was viewed under a field-emission SEM (HFS-2).

After standard fixation and dehydration for SEM, some of the materials were fractured by the epon-freeze cracking method (Shimada et al., 1976) prior to critical point drying in order to observe the lumen of the capillary.

\section{Results}

The pecten oculi of Uroloncha striata domestica was found to consist mainly of numerous capillaries of varying calibre, pigmented cells and a superficial membrane which enveloped the pecten and separated it from the vitreous body (Fig. 1). The pigmented cells were observed as a loosely packed group existing between the capillary walls (Fig. 1). The lumen of the capillaries was lined by a single layer of endothelial cells, which provided numerous cytoplasmic processes on both the luminal and basal surfaces (Figs. 1 and 2). Without treatment as above, clear SEM observation of the basal surface of the capillary was very difficult due to the presence of a superficial membrane covering the pecten oculi (Fig. 3). The digestive treatment effectively removed not only the superficial membrane but also the basement membrane-like materials surrounding the basal surface of the capillary endothelium and clearly visualized a dense network of capillaries (Fig. 4). The pericytes on the stromal surface of the capillary wall were sparse in distribution and were in close contact with the endothelial cells of the capillary through long, branching cytoplasmic processes (Figs. 5 and 6). When observed with the SEM, the basal processes of the endothelial cells of the pectineal capillary were seen to be composed of microfolds which in general met at right angles with the long axis of the capillary and frequently formed labyrinthine anastomoses (Fig. 7). In accordance with the boundary of the endothelial cells, stereophotographs of the basal surface of the capillary endothelium revealed shallow furrows, in which the distribution of microfolds was sparse (Fig. 8).

In fractured surface view, densely packed, long microvilli occupied the capillary lumen (Fig. 9). Some of the microvilli were forked at their base, most of them were moderately waved, and a few microfolds were recognized among the microvilli (Fig. 10).

\section{Discussion}

The pecten represents the most complex nutritive device of the avian eye as regard gross and fine architecture. The pecten oculi consists of a well vascu- 
larized bed surrounded by a pigment cell layer. TEM examinations of the capillary of the pecten oculi have revealed that its endothelial cells possess very unusual structures gencrally described as microvilli or folds, and that the outer wall of the capillary is surrounded by discontinuous but distinct layers of finely granulated materials similar to the basement membrane (Tanaka, 1960; Semba, 1962; Seaman and Storm, 1963; Fischlschweiger and O'Rahilly, 1966; Raviola and Raviola, 1967 ; Welsch, 1972 ; Jasiński, 1973; Dieterich et al., 1973; Dieterich and Dieterich, 1974; Amemiya, 1980). Concerning the pericytes, many authors (Raviola, 1967; Jasiński, 1973; Dieterich et al., 1973; Amemiya; 1980) have recognized their existence throughout the capillary walls regardless of the capillary diameter, while a few authors (Tanaka, 1960; Seaman and Storm, 1963) have denied the existence of pericytes on the true or small calibre capillaries of the pecten oculi. The present study confirmed their existence in the pectineal capillaries by SEM examination. Since the capillary wall of the pecten oculi is invested with such extracellular components as the superficial membrane and basement membrane-like materials surrounding the basal surface of the capillary endothelium, it cannot usually be observed in SEM images. A modification of Evan's method, however, made it possible to visualize the basal surface of the capillary of the pecten oculi. In such SEM pictures, the pericytes on the stromal surface of the capillary wall of the pecten oculi of Uroloncha striata domestica were in close contact with the endothelial cells of the capillary, although their distribution was sparse. The nature and physiological significance of the pericytes of the pectineal capillary remain unknown from only this study, and detailed experimental work will be required in the future to resolve this difficult question.

The most striking feature of the endothelial cells of the capillary of the pecten oculi is probably the numerous processes at both margins, which appear to be unique in the vertebrate vascular system. There is disagreement among different authors concerning the precise morphology of these cytoplasmic processes. Some workers (Semba, 1962 ; Seaman and Storm, 1963 ; Raviola and Raviola, 1967 ; Jasinski, 1973 ; Dieterich et al., 1973; Dieterich and Dieterich, 1974) have asserted that these structures are folds or lamellae, whereas others (Tanaka, 1960 ; Fischlschweiger and O'Rahilly, 1966; Welsch, 1972) have described them as microvilli. Most of these authors developed their conclusions on the basis of serial or tangential sections of the cytoplasmic processes of the endothelial cells. It was clarified in the present SEM study, however, that the basal processes of the endothelial cells were composed of microfolds anastomosing with each other and that their luminal processes were composed of both microvilli and microfolds, although the distribution ratio of microfolds in the luminal surface of the endothelial cells still remains unknown.

Histochemical and biochemical investigations have demonstrated a very high content of alkaline phosphatase in the pecten oculi (Welsch, 1972; Bawa and YashRoy, 1972). Such a wealth of enzymes in the endothelial cells of the capillaries of the pecten oculi may demand extensive development of the membrane system like the basal and luminal differentiations. The discrepancy between microvilli and microfolds might depend on the need for enlargement of the surface area for membrane-bound enzymes. 


\section{References}

1) Amemiya, T.: A transmission and scanning electron microscopic study of the pecten of the chick eye. Acta Soc. Ophthalmol. Jpn. $84: 295-303,1980$. (in Japanese)

2) Bawa, S. R. and R.C. YashRoy: Effect of dark and light adaptation on the retina and pecton of chicken. Exp. Eye Res. 13: 92-97, 1972.

3) Dieterich, C.E., H. J. Dieterich, M. A. Spycher and M. Pfautsch: Fine structural observations of the pecten oculi capillaries of the chicken. Ereeze-etching, scanning and transmission electron microscopic investigations. Z. Zellforsch. 146: 473489, 1973.

4) Dieterich, H. J. and C.E. Dieterich: Licht- und elektronenmikroskopische Untersuchungen am Pecten Oculi verschiedener Vogelarten. Verh. Anat. Ges. 68: 467-478, 1974.

5) Evan, A.P., W.G. Dail, D. Dammrose and C. Palmer: Scanning electron microscopy of cell surfaces following removal of extracellular material. Anat. Rec. 185 : 433-446, 1976.

6) Fischlschweiger, W. and R. O'Rahilly: The ultrastructure of the pecten oculi in the chick. Acta anat. 65: 561-578,
1966.

7) Jasiński, A.: Fine structure of capillaries in the pecten oculi of the sparrow, Passer domesticus. Z. Zellforsch. 146: 281-292, 1973.

8) Raviola, E. and G. Raviola: A light and electron microscopic study of the pecten of the pigeon eye. Am. J. Anat. 120: 427-462, 1967.

9) Seaman, A. R. and H. Storm: A correlated light and electron microscope study on the pecten oculi of the domestic fowl (Gallus domesticus). Exp. Eye Res. 2: 163-172, 1963.

10) Semba, T.: The fine structure of the pecten studied with the electron microscope. I. Chick pecten. Kyushu J. Med. Sci. 13 : 217-232, 1962.

11) Shimada, T., K. Ota, M. Yamamoto and M. Murakami : Epon-freeze cracking for scanning electron microscopy. Kurume Med. J. 23 : 139-143, 1976.

12) Tanaka, A.: Electron microscopic study on the avian pectines I. Dobutsugaku Zasshi. 69: 314-317, 1960. (in Japanese)

13) Welsch, U.: Enzymhistochemische und feinstrukturelle Beobachtungen am Pecten oculi von Taube (Columba livia) und Lachmöwe (Larus ridibundus). Z. Zellforsch. 132 : 231-244, 1972. 


\section{PLATES}




\section{Explanation of Figures}

\section{Plate I}

Fig. 1. Fractured surface of the pecten oculi of Uroloncha striata domestica. The pecten oculi contains numerous capillaries of varying calibre. Arrows indicate the superficial membrane covering the pecten surface. $\times 1,500$

Fig. 2. Fractured surface of a capillary of the pecten oculi. The endothelial cell (EC) of the capillary provides numerous cytoplasmic processes on the luminal and basal surfaces. $\times 7,500$

Fig. 3. Low-power scanning electron micrograph of the pecten surface without collagenase-HCl treatment. A superficial membrane obscures the surface structure of the capillary wall. $\times 290$

Fig. 4. Low-power scanning electron micrograph of the pecten surface after treatment with collagenase and $\mathrm{HCl}$. Note the dense network of the capillaries. AB: Apical bridge. $\times 140$ 

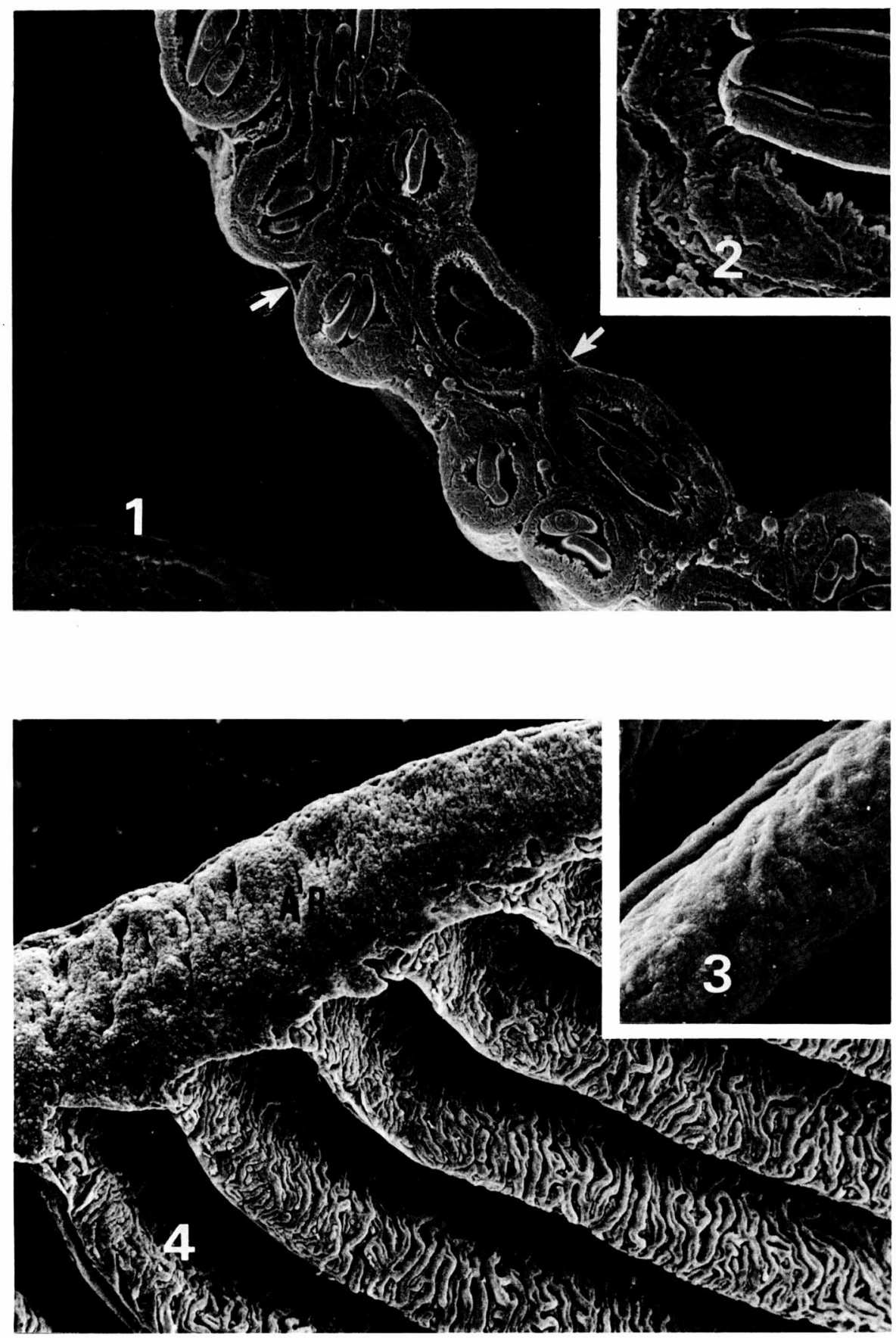

A. Sugita, et al. 


\section{Plate II}

Fig. 5. Scanning electron micrograph of the basal surface of a capillary of the pecten oculi. Pericytes $(P)$ are distributed sparsely throughout the entire capillary wall. The spaces between the capillaries are occupied by pigmented cells. $\times 1,970$

Fig. 6. Higher magnification of a pericyte on the capillary wall. The pericyte is attached to the capillary wall by long, branching cytoplasmic processes (arrows). $\times 5,400$

Fig. 7. High-power scanning electron micrograph of the basal surface of an endothelial cell of a capillary. The basal processes of the endothelial cell are composed of microfolds anastomosing with each other. PC: Pigmented cell. $\times 8,250$ 

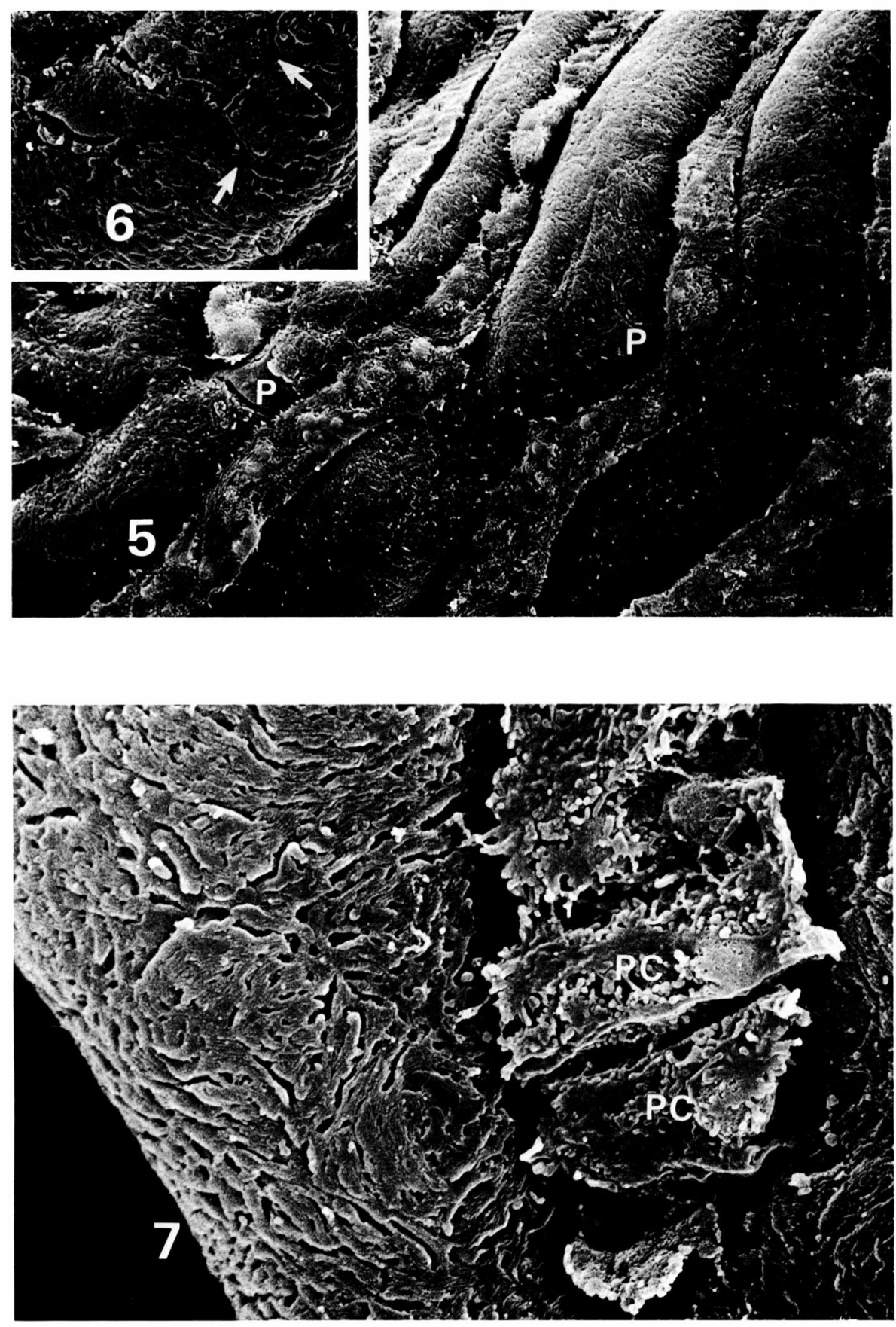

A. Sugita, et al. 


\section{Plate III}

Fig. 8. Stereophotography of the basal surface of a capillary. Arrows denote the boundary of an endothelial cell. $\times 3,860$

Fig. 9. Scanning electron micrograph of the fractured surface of a capillary. The capillary lumen is occupied by numerous microvilli. $\times 10,500$

Fig. 10. Scanning electron micrograph of the luminal surfaces of a capillary. Arrows denote microfolds. $\times 17,600$ 

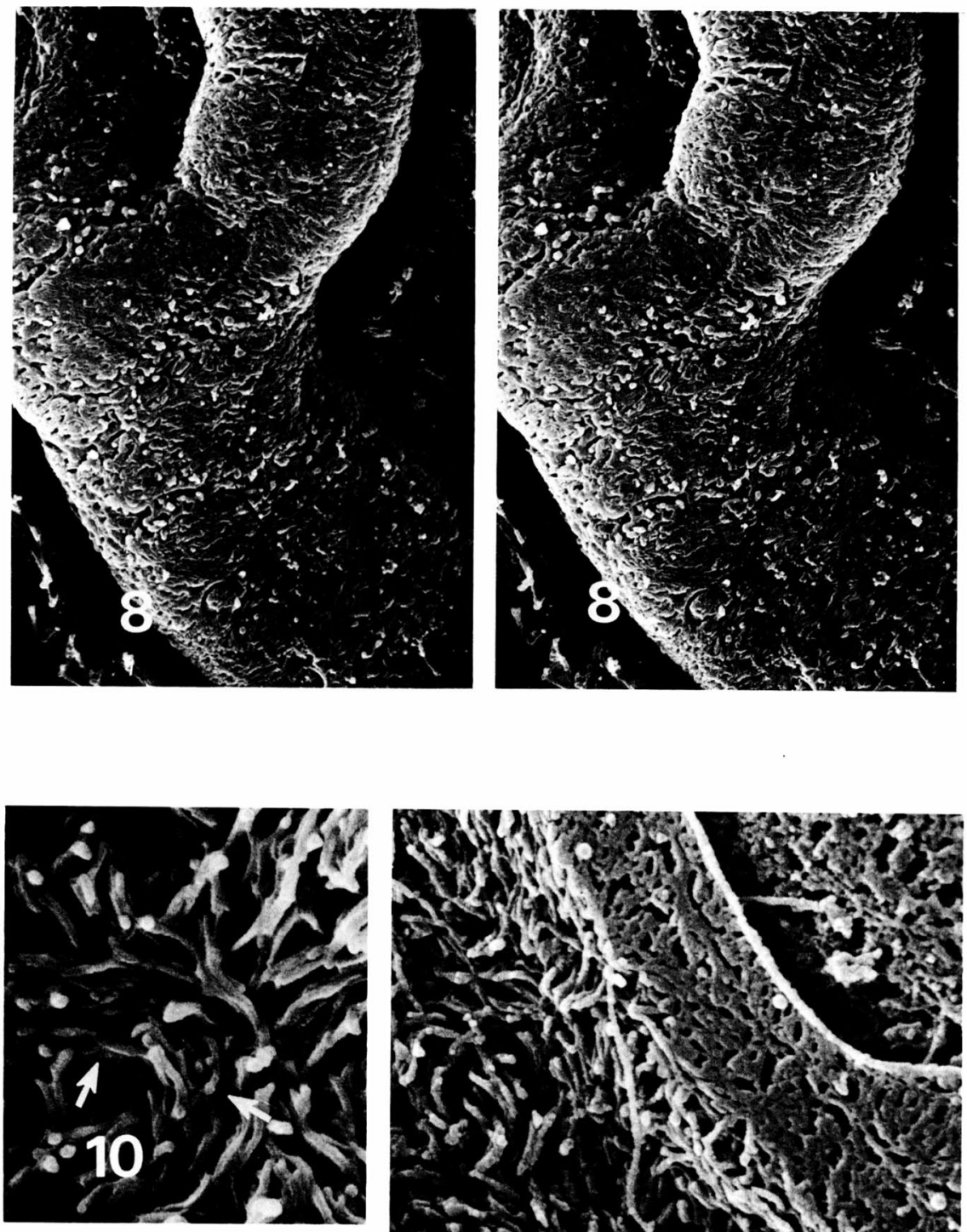

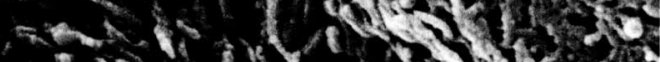

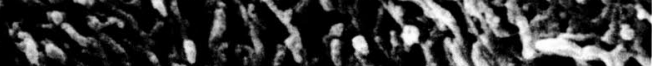

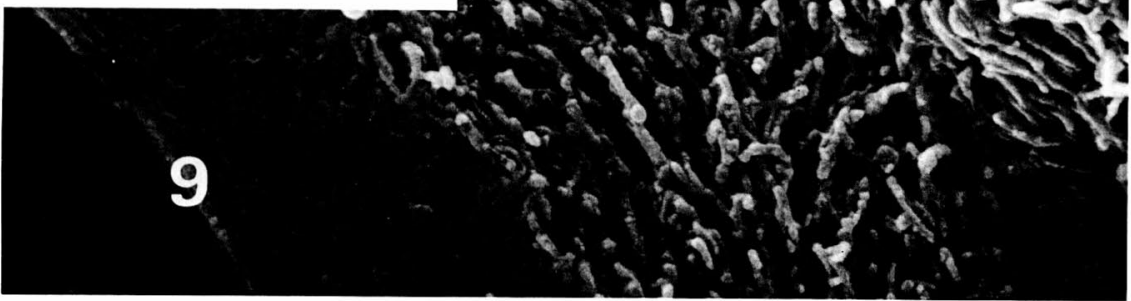

A. Sugita, et al. 